\title{
Posterior gastric diverticulum mimicking adrenal adenoma on imaging
}

\author{
Felix K Jebasingh, ${ }^{1}$ Dukhabandhu Naik, ${ }^{2}$ Anuradha Chandramohan, ${ }^{3}$ \\ Mazhuvanchary Jacob Paul ${ }^{4}$
}

${ }^{1}$ Department of Endocrinology, Diabetes and Metabolism, Christian Medical College, Vellore, Tamil Nadu, India ${ }^{2}$ Department of Endocrinology, Christian Medical College, Vellore, Tamil Nadu, India ${ }^{3}$ Department of Radiology, Christian Medical College, Vellore, Tamil Nadu, India ${ }^{4}$ Department of Endocrine Surgery, Christian Medical College, Vellore, Tamil Nadu, India

Correspondence to Dr Dukhabandhu Naik, drnaik2000@gmail.com

Accepted 6 December 2014

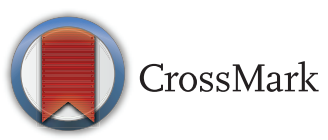

To cite: Jebasingh FK, Naik D, Chandramohan A, et al. BMJ Case Rep Published online: [please include Day Month Year] doi:10.1136/bcr-2014207059

\section{DESCRIPTION}

A 63-year-old man on a permanent pacemaker for complete heart block presented with one episode of haemoptysis. Clinical examination of the thorax was unremarkable. A contrast-enhanced CT scan showed normal lungs and a well-defined lesion in the left adrenal gland, apparently separated from the posterior wall of the stomach in all the images. It measured $3 \mathrm{~cm}$ with a density of $6-10$ Hounsfield units (HU; figure 1). Postcontrast washout was not performed as the HU density was low. In view of a normal hormonal profile, the patient was advised to review after 6 months. A repeat $\mathrm{CT}$ of the abdomen performed at review showed a similar-sized mass in the region of the left adrenal gland, but this time an air-fluid level was

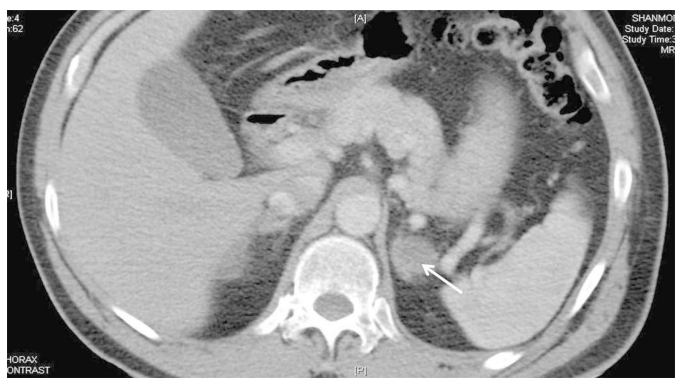

Figure 1 Axial section of contrast-enhanced CT scan showing a well-defined low-density left supra-renal lesion (arrows).

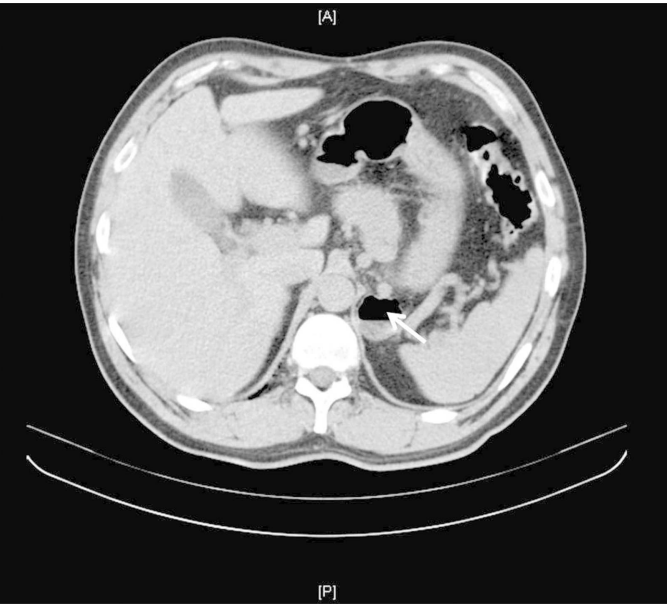

Figure 2 Axial section of contrast-enhanced CT scan performed at 6 months follow-up showing a similar-sized left supra-renal lesion with air fluid level (arrows).

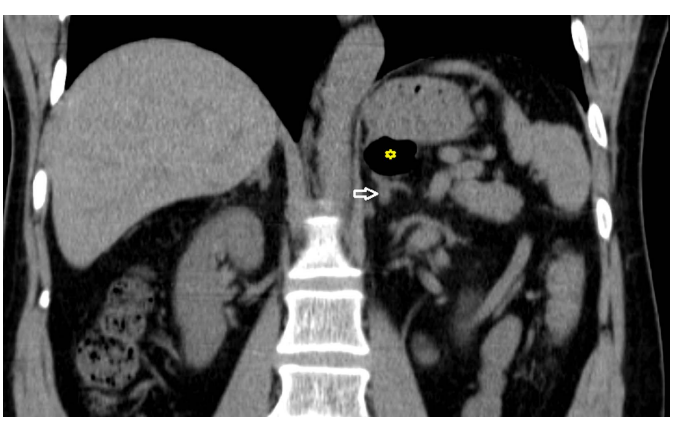

Figure 3 Coronal section of the same follow-up CT revealing normal left adrenal gland (open arrow) and the lesion was in continuity with the stomach (asterisk).

made out on axial sections (figure 2), the section of image seen corresponded to the level of the initial image. Additionally, on the coronal sections, the entire left adrenal gland could be seen separate from the lesion, which was in continuity with the stomach (figure 3 ) and thus diagnostic of a posterior wall gastric diverticulum. Since the patient had no symptoms related to the gastric diverticulum, no treatment was offered for it and he was advised clinical follow-up only. The prevalence of gastric diverticula is $0.1-2.6 \%$ and can be either acquired or congenital. ${ }^{1}$ During embryonic development, diverticulae of the posterior wall of the gastric cardia can herniate through the dorsal mesentery prior to its fusion with the left posterior gastric body and thus simulate an adrenal mass. ${ }^{23}$

\section{Learning points}

- Gastric diverticulum simulating an adrenal tumour is rare, but must be considered in an asymptomatic patient to avoid unnecessary biochemical investigation.

- Reviewing both axial and coronal sections of the abdominal CT is useful in distinguishing adrenal from non-adrenal lesions such as a gastric diverticulum.

Contributors FKJ, DN and MJP were involved in patient management. FKJ and DN wrote the manuscript. FKJ, DN, AC and MJP were involved in manuscript review and revision.

\section{Competing interests None.}

Patient consent Obtained. 
Provenance and peer review Not commissioned; externally peer reviewed.

\section{REFERENCES}

1 Rashid F, Aber A, Iftikhar SY. A review on gastric diverticulum. World J Emerg Surg 2012;7:1
2 Schwartz A, Goiney R, Graney D. Gastric diverticulum simulating an adrenal mass: CT appearance and embryogenesis. Am J Roentgenol 1986;146:553-4.

3 Araki A, Shinohara M, Yamakawa J, et al. Gastric diverticulum

preoperatively diagnosed as one of two left adrenal adenomas. Int J Urol 2006;13:64-6.

Copyright 2014 BMJ Publishing Group. All rights reserved. For permission to reuse any of this content visit

http://group.bmj.com/group/rights-licensing/permissions.

BMJ Case Report Fellows may re-use this article for personal use and teaching without any further permission.

Become a Fellow of BMJ Case Reports today and you can:

- Submit as many cases as you like

- Enjoy fast sympathetic peer review and rapid publication of accepted articles

- Access all the published articles

- Re-use any of the published material for personal use and teaching without further permission

For information on Institutional Fellowships contact consortiasales@bmjgroup.com

Visit casereports.bmj.com for more articles like this and to become a Fellow 